\title{
WATER MITE PREDATION ON ZOOPLANKTON OF A TROPICAL LAKE
}

\author{
CASSANO, C. R., CASTILHO-NOLL, M. S. M. and ARCIFA, M. S. \\ Departamento de Biologia, FFCLRP, Universidade de São Paulo, CEP 14040-901, Ribeirão Preto, SP, Brazil \\ Correspondence to: Marlene Sofia Arcifa, Departamento de Biologia, FFCLRP, Universidade de São Paulo, \\ Av. Bandeirantes, 3900, CEP 14040-901, Ribeirão Preto, SP, Brazil, e-mail: marcifa @usp.br \\ Received January 14, 2002 - Accepted March 20, 2002 - Distributed November 30, 2002
}

(With 2 figures)

\begin{abstract}
Water mite (Krendowskia sp.) predation on zooplanktonic species from Lake Monte Alegre (São Paulo State, Brazil) was tested in laboratory experiments. One cladoceran, Daphnia gessneri, two copepods, Tropocyclops prasinus and Thermocyclops decipiens, and Chaoborus larvae III and IV were supplied as prey to adult mites. The cladoceran Ceriodaphnia cornuta was used in the experiment with mite nymphs. Only $D$. gessneri was preyed on by mites, at an average rate of 7 ind./mite/day, at $23-24^{\circ} \mathrm{C}$. Although Chaoborus was not eaten by the predator in the experiment, in direct observations older larvae were seen to be seized by several mites, both predators and prey sinking to the bottom of the vessel. Adult Daphnia was grabbed by its dorsal side, swimming together with the mite. There was an increase in predatory activity two hours after sunset.
\end{abstract}

Key words: zooplankton predation, experiments, Hydracarina, Krendowskia sp.

\section{RESUMO}

\section{Predação do zooplâncton de um lago tropical por ácaros aquáticos}

A predação do zooplâncton por ácaros aquáticos (Krendowskia sp.) do Lago Monte Alegre (Estado de São Paulo, Brasil) foi testada em experimentos de laboratório. Um cladócero, Daphnia gessneri, dois copépodos, Tropocyclops prasinus e Thermocyclops decipiens e larvas III e IV de Chaoborus foram oferecidos como presas a ácaros adultos. O cladócero Ceriodaphnia cornuta foi usado em experimentos com ninfas de ácaros. Apenas $D$. gessneri foi predada pelos ácaros, a uma taxa média de 7 ind./ácaro/dia, a $23-24^{\circ} \mathrm{C}$. Embora Chaoborus não tenha sido comido pelo predador no experimento, nas observações diretas, grupos de ácaros foram vistos agarrados a larvas III e IV. Ao agarrarem os caoborídeos, os ácaros paravam de nadar e afundavam com a presa. Ainda nas observações diretas, os ácaros foram vistos agarrados ao dorso de Daphnia adultas e, nesta ocasião, continuavam nadando com a presa. Foi observado aumento na atividade predatória duas horas após o pôr-do-sol.

Palavras-chave: predação de zooplâncton, experimentos, Hydracarina, Krendowskia sp.

\section{INTRODUCTION}

In the limnetic zone of Brazilian freshwater water bodies, invertebrate predators are mostly Chaoboridae larvae, Notonectidae, cyclopoid copepods, the rotifer Asplanchna, lacking Mysidacea and the large cladoceran predators. Predation can be an important force in structuring plankton community (Zaret, 1980), considering the high mortality rates imposed to their prey. The extinction or absence of cladocerans in lakes can be, in some cases, caused by invertebrate predation (Threlkeld et al., 1980).

Water mites are commonly found in the littoral zone and benthos of lakes, and their presence in the plankton has been considered an occasional event. But interaction with zooplankton has been taken into account when mites were found in relatively large densities in the limnetic zone, reaching values above 100 ind. $\mathrm{m}^{-3}$ (Gliwicz \& 
Biesiadka, 1975; Riessen, 1982a). They can prey on microcrustaceans, such as cladocerans and copepods (Gliwicz \& Biesiadka, 1975; Riessen, 1982b; Matveev et al., 1989; Butler \& Burns, 1991, 1993), having a significant impact on prey populations (Gliwicz \& Biesiadka, 1975). They also migrate vertically (Riessen, 1980; Perticarrari, 2000), some species spending part of the day at the bottom, at least when dissolved oxygen is not depleted (Perticarrari, op. cit.), as they avoid low oxygen concentrations (Gliwicz \& Biesiadka, 1975).

They swim erratically, changing directions and experiencing a small encounter radius with their prey (Riessen, 1982b). They pierce the prey and after predigesting it with enzymes, they pump the content, leaving the internal prey tissues partially or totally damaged, including the eye (Riessen, op. cit.).

As water mites became important in the plankton of Lake Monte Alegre, reaching up to 312 ind. $\mathrm{m}^{-3}$ (Fileto, 2001), this investigation was undertaken to evaluate their predation on planktonic organisms. Experiments were made in the laboratory, cladocerans, copepods, and chaoborid larvae being supplied as prey. In addition, direct observations on their predatory behavior were made.

\section{STUDY AREA}

Lake Monte Alegre $\left(21^{\circ} 11^{\prime} \mathrm{S}, 47^{\circ} 43^{\prime} \mathrm{W}\right)$ is a small, shallow, eutrophic reservoir (area 7 ha., $\mathrm{Z} \max .=5 \mathrm{~m}, \overline{\mathrm{z}}=2.9 \mathrm{~m}$ ). Located in southeastern Brazil, at an altitude of $500 \mathrm{~m}$, as a result from the damming of Laureano Creek in 1942, which belongs to Pardo River basin. It may stratify for relatively long periods in the warm season, leading to oxygen depletion near the bottom (Arcifa et al., 1990). As the outlet is superficial and the dam is not manipulated by man, it functions as a small lake, with a retention time of $c a .45$ days. The region is characterized by a tropical climate, with a marked dry-cool season (May-September) and a wet-warm season (October-April).

\section{MATERIAL AND METHODS}

\section{Preparation of the experiments}

Four experiments were undertaken in the laboratory with the water mite Krendowskia sp. and five different organisms: two cladocerans, Daphnia gessneri and Ceriodaphnia cornuta, two copepods, Tropocyclops prasinus and Thermocyclops decipiens, and the dipteran Chaoborus larvae III and IV. Three experiments were run with adult mites and one with nymphs.

Water mites were collected in the lake with a $190 \mu \mathrm{m}$ net by vertical hauls. In the laboratory, 6 mites were placed individually in 600 ml-beakers, filled with lake water filtered in glass fiber filters. The animals were acclimated for a minimum of 24 hours, in dim light, without food, at room temperature of $23-24^{\circ} \mathrm{C}$. Microcrustaceans were collected in the lake with a $60 \mu \mathrm{m}$ net and Chaoborus larvae with a $190 \mu \mathrm{m}$ net. Prey organisms were placed in 600 ml-beakers, with filtered lake water.

All the experiments lasted 24 hours, in dim light, at a temperature of $23-24^{\circ} \mathrm{C}$.

Treatments were: Predator present $(\mathrm{P}+)$ and Predator free $(\mathrm{P}-)$, with 6 replicates each. One mite per vessel was used for avoiding interference among predators as found by Matveev et al. (1989).

At the end of the experiments, the mites were taken from the $\mathrm{P}+$ treatment and dead and live preys were counted in both treatments. The dead ones in the $\mathrm{P}+$ treatment were scrutinized for clues of mite attack.

\section{Experiment a}

Period: Summer 1999/2000

Prey and length: adult cladoceran Daphnia gessneri: $1.18 \pm 0.17 \mathrm{~mm}$ ind. $\left.\mathrm{L}^{-1}\right)$

Prey number/replicate: 20 ind./beaker (33.3

Predator length: $1.16 \pm 0.17 \mathrm{~mm}$

Predator number/replicate: 1 ind./beaker (1.7 ind. $\mathrm{L}^{-1}$ )

\section{Experiment b}

Period: Summer 2000

Prey and length: adult cladoceran Ceriodaphnia cornuta: $0.40 \pm 0.04 \mathrm{~mm}$ ind. $\mathrm{L}^{-1}$ )

Prey number/replicate: 20 ind./beaker (33.3

Predator length: $0.67 \pm 0.03 \mathrm{~mm}$ (nymph) ind. $\mathrm{L}^{-1}$ )

Predator number/replicate: 1 ind./beaker (1.7

Experiment c

Period: Autumn 2000

Prey and length: Chaoborus instar III (4.49 \pm $0.37 \mathrm{~mm})$ and IV $(6.65 \pm 0.51 \mathrm{~mm})$

Prey number/replicate: 15 ind./beaker (10 larvae III + 5 larvae IV) $\left(25\right.$ ind. $\left.^{-1}\right)$

Predator length: $1.16 \pm 0.17 \mathrm{~mm}$ 
Predator number/replicate: 1 ind./beaker (1.7 ind. $\left.\mathrm{L}^{-1}\right)$

\section{Experiment $\mathrm{d}$}

Period: Autumn 2000

Prey and length: copepods Tropocyclops prasinus $(0.52 \pm 0.02 \mathrm{~mm})$ and Thermocyclops decipiens $(0.76 \pm 0.05 \mathrm{~mm})$ ind. $\left.\mathrm{L}^{-1}\right)$

Prey number/replicate: 15 ind./beaker $(25$

Predator length: $1.14 \pm 0.03 \mathrm{~mm}$ ind. $\left.\mathrm{L}^{-1}\right)$

Predator number/replicate: 1 ind./beaker (1.7

\section{Direct observations}

Predatory behavior of water mites was also observed in $600 \mathrm{ml}$ glass bottles and at a stereomicroscope. One of the observations at the stereomicroscope was made between 18 and 21 $\mathrm{h}$, using a red filter in the incident light.

\section{Statistical treatment}

The comparison between treatments was made by the Student's $t$-test or Mann-Whitney, depending on the data distribution $(\mathrm{p}<0.05)$.

\section{RESULTS}

\section{Experiments}

In experiment $a$, the average number of Daphnia gessneri which survived in the $\mathrm{P}+$ treatment was of 12 individuals and in the $\mathrm{P}$ treatment it was of 19 individuals (Fig. 1a). The difference between means was statistically significant $(\mathrm{t}=3.13, \mathrm{P}=0.01, \mathrm{~N}=6)$.

In experiment $b$, the average number of survivors of Ceriodaphnia cornuta was 17.8 and 16.7 in the $\mathrm{P}+$ and $\mathrm{P}$ - treatments, respectively (Fig. 1b). There was no statistical difference between them. The difference between this experiment and the others is that mite nymphs were used, as adults were not found at the occasion of the experiment. In experiment $c, 14.5$ and 14.8 Chaoborus larvae survived in the $\mathrm{P}+$ and $\mathrm{P}-$ treatments, respectively (Fig. 1c). The means were not statistically different.

In experiment $d$, the average number of live copepods was 14.3 and 14.7 in the $\mathrm{P}+$ and $\mathrm{P}-$ treatments, respectively (Fig. 1d). There was no statistical difference between means.
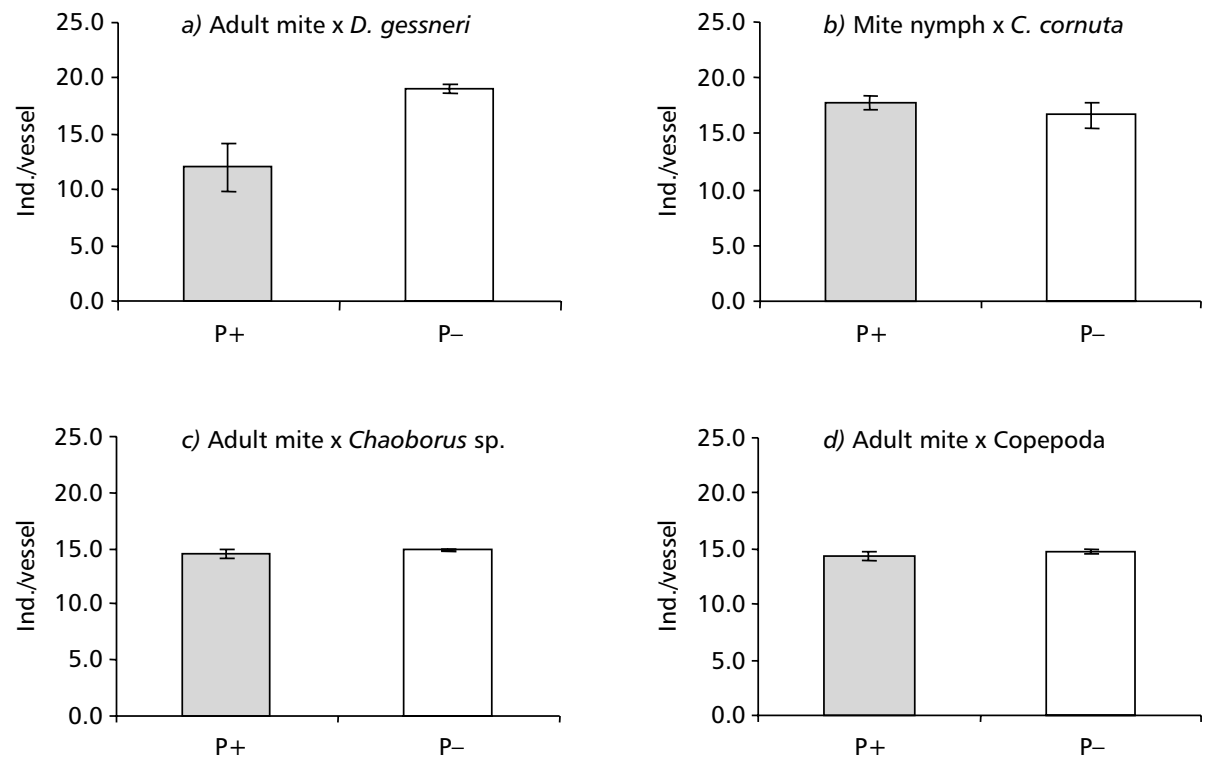

Fig. 1 - Average and standard error of live prey in both treatments in each experiment. $(\mathrm{P}+=$ predator present, $\mathrm{P}-=$ predator free; initial prey number was 20 in experiments $a$ and $b$ and 15 in $c$ and $d$.) 


\section{Direct observations}

Water mites $x$ Chaoborus larvae

In a bottle with high densities of both predator and prey, several water mites seized one larva, stopped swimming, and sank slowly to the bottom. Many larvae were grabbed by mites, a frequent sinking movement occurring in the bottle.

\section{Water mites $x$ Daphnia gessneri}

Each water mite caught one Daphnia and once grabbed to its dorsal region swam together with it.

\section{Time activity}

The observations starting at sunset and ending at $21 \mathrm{~h}$, using red illumination, showed that predation activity increased in the period, with mites being more active between 20 and $21 \mathrm{~h}$.

\section{DISCUSSION}

Of the five organisms supplied to the water mite Krendowskia sp., in the experiments, only the cladoceran Daphnia gessneri was preyed upon by adults, whereas copepods and Chaoborus larvae were not. The nymphs did not prey on the cladoceran Ceriodaphnia cornuta. Several papers also reported that cladocerans were selectively preyed on by water mites in relation to copepods (Gliwicz \& Biesiadka, 1975; Riessen, 1982b; Matveev et al., 1989; Butler \& Burns, 1991). Some cladoceran species are more sensitive to predation by mite than others; Piona exigua preferred Daphnia carinata and D. obtusa than Ceriodaphnia dubia in experiments undertaken by Butler \& Burns (1991). According to these authors, copepods, such as Boeckella, were able to detect the mite and flee the area before being in the encounter radius of the predator. However, this copepod can be a mite prey when its escape reaction erroneously directs it towards the predator.

Riessen (1982b) found the following order of prey preference by adult mites: Bosmina $>$ Daphnia, Ceriodaphnia $>$ Chydorus $>>$ Diaphanosoma, Diaptomus $>$ Mesocyclops. Daphnia was selectively preyed on according to size, up to 1.3$1.5 \mathrm{~mm}$. Adult size of Daphnia gessneri in this paper is below the limit reported for predation by mite. But water mites can eat prey 2-3 times their own lengths, although a larger prey can have a higher escape ability counterbalancing any increase in preference for them (Butler \& Burns, 1991). Nymphs preferred Chydorus > Bosmina, Ceriodaphnia being a secondary prey or rarely preyed on (Riessen, 1982b, 1985; Butler \& Burns, 1993). Balseiro (1992) also found preference of the mite Limnesia patagonica for Bosmina longirostris, whereas Ceriodaphnia dubia was not eaten, even when offered individuals of Bosmina's size. Wong (1981, in Butler \& Burns, 1991) observed that Ceriodaphnia has a higher escape ability than Bosmina. The results presented here that mite nymphs do not prey on Ceriodaphnia agree with Balseiro (1992).

Although not eaten by the predator in the experiments, in the direct observations Chaoborus larvae were seen to be seized by groups of mites. It seems that one prey can be shared by several predators as reported by Proctor \& Pritchard (1990), who observed nine mites eating one chaoborid larva. It is likely that predation on chaoborid larvae is part of a group behavior instead of an individual activity.

The number of prey caught per mite is dependent on a series of factors. It increases with temperature (Davids et al., 1981) and is dependent also on interference among predators, increasing up to 20-fold when there is only one mite or stage per experimental vessel (Riessen, 1982b; Matveev et al., 1989). Predation rate of the water mite Krendowskia sp. in this paper, at $23-24^{\circ} \mathrm{C}$, was ca.7 Daphnia/mite/day. Riessen (1982b) found, at temperatures of $15-21^{\circ} \mathrm{C}$, average predation rates of 10-15 prey/mite/day. Butler \& Burns (1993) reported rates of 9-25 favorite prey/predator/day, at $15^{\circ} \mathrm{C}$. Gliwicz \& Biesiadka (1975) estimated predation of 3-4 cladocerans/mite/day, at $27-31^{\circ} \mathrm{C}$, but they believe that this rate was underestimated, supposing that 10-20 cladocerans/mite/day would be more realistic. Matveev et al. (1989) found the highest rates, $24-168$ cladocerans/mite/day, at $27^{\circ} \mathrm{C}$. In Lake Monte Alegre, mite predation rate is close to Chaoborus instar IV predation rate, estimated in 9-14 cladocerans/larva/day (M. S. M. CastilhoNoll \& M. S. Arcifa, in preparation).

Experiments with Bosmina tubicen, from Lake Monte Alegre, offered as prey have not been made due to difficulties in finding them in the field or cultivating them in the laboratory. However, considering that Bosmina is reported as a favorite prey of water mite species by several authors, it is possible that it is also a mite prey in this lake. 

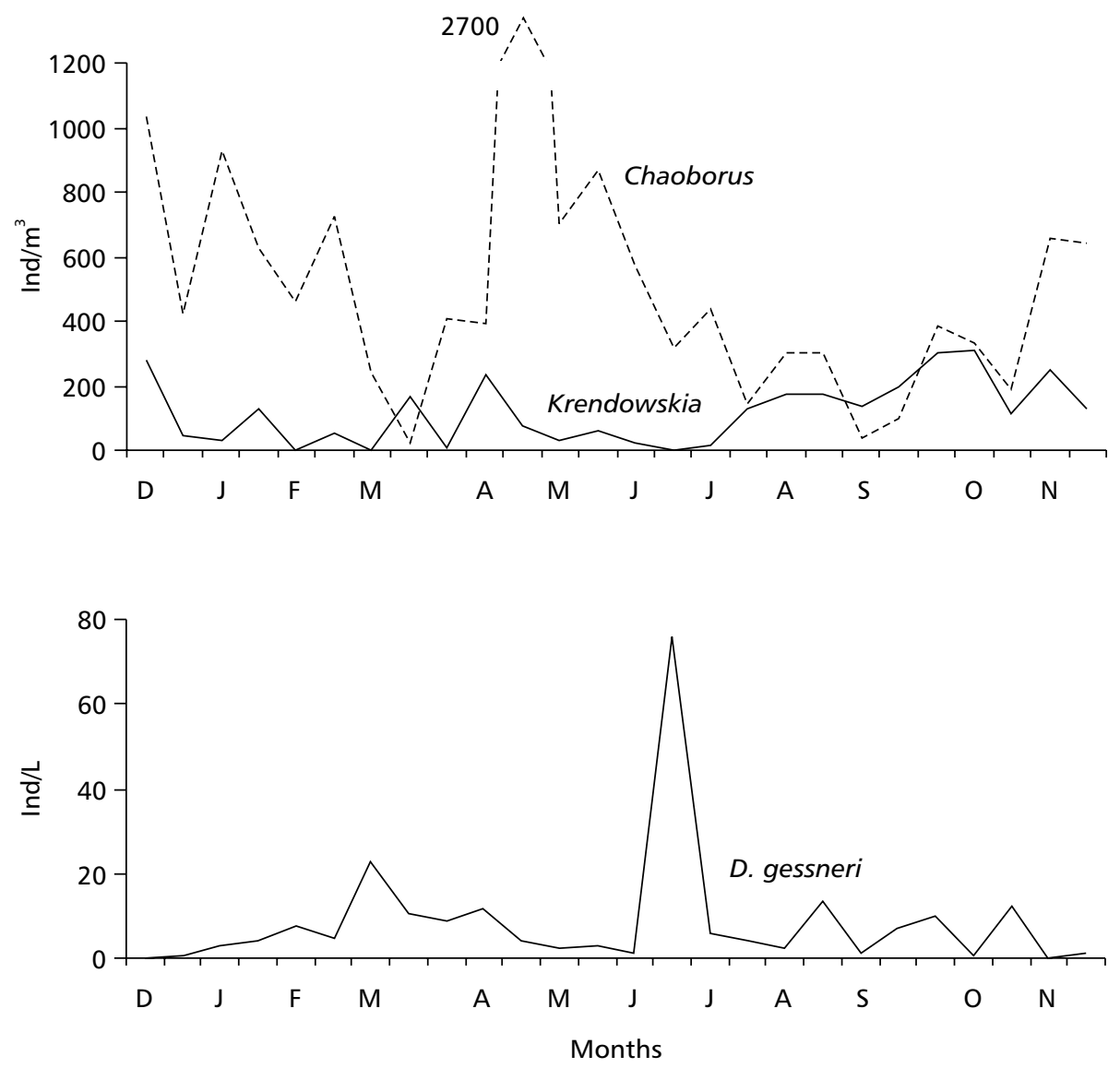

Fig. 2 - Density fluctuations of the predator, Krendowskia sp., and prey, Daphnia gessneri and Chaoborus sp. in Lake Monte Alegre, from December 1998 to November 1999. Source: Fileto (2001).

Bosmina is the favorite cladoceran prey of Chaoborus in the lake (Arcifa, 2000; M. S. M. Castilho-Noll \& M. S. Arcifa, in preparation).

Balseiro (1992) concluded that densities of mites should be 200-300 ind. $\mathrm{m}^{-3}$ to explain half of Bosmina mortality. Matveev et al. (1989) found that Daphnia death rates were correlated with mites when their densities reached 400 ind. $\mathrm{m}^{-3}$. In Lake Monte Alegre, up to 312 mites. $\mathrm{m}^{-3}$ were recorded in 1998/1999 (Fileto, 2001), and aggregates of 1,800-2,000 ind. $\mathrm{m}^{-3}$ were found at night, in the summer of 1999 (Perticarrari, 2000). M. S. M. Castilho-Noll \& M. S. Arcifa (in preparation) found in mesocosm experiments in the lake that Chaoborus instar IV, at densities up to 141 ind. $\mathrm{m}^{-3}$, were responsible for decreasing Daphnia gessneri population growth, due to an increase in death rates. Chaoborids prey on the cladocerans D. gessneri and Bosmina tubicen (Arcifa, 2000; M. S. M. Castilho-Noll \& M. S. Arcifa, in preparation), and supposedly mites also prey on the latter species, besides Daphnia. Taking into account the predator densities in the lake ( $c a .200$ chaoborid instar IV.m ${ }^{-3}$ and 300 mites. $\left.\mathrm{m}^{-3}\right)$, a high predation pressure might be expected on both populations. B. tubicen is also the favorite prey of chaoborid instar III (Arcifa, 2000), meaning that predation pressure on this species could be even higher than on Daphnia. In the 80's, Bosmina tubicen was more frequent and abundant (up to 90 ind. $\mathrm{L}^{-1}$ ) (Arcifa et al., 1992) than recently (max. 4 ind. $\mathrm{L}^{-1}$, usually around 0.01 ind. $\mathrm{L}^{-1}$ ) (Fileto, 2001). At that time, Chaoborus larvae were present in the lake but water mites were absent. The explanation for the recent sharp decrease and virtual disappearance 
of Bosmina, in some occasions, might be likely related to predation pressure by both invertebrates.

Water mites in general suffer a low predation pressure in Lake Monte Alegre. They contributed a small proportion to the diet of young fish associated to macrophytes (1.4\%-1.6\%) (Meschiatti $\&$ Arcifa, 2002) and none to adult ones (Arcifa \& Meschiatti, 1993). They are distasteful to fish and invertebrate predators, surviving an attack and rejection by them (Kerfoot et al., 1980; Riessen, 1980). Eriksson et al. (1980) reported that water mites were not a preferred fish prey and were most abundant in the presence of fish, as these decreased the densities of invertebrate predators of mites. Matveev \& Martinez (1990) found, in experiments, that fish only ate mites after a period of low food supply and lack of an alternative prey. They also found that mite and zooplanktivorous fish predation rates were similar (100 prey/predator/day), in a South American lake. According to these authors, water mites in that lake fulfill three requirements for suppressing a prey: high predation rates, quick numerical response, and protection from fish. In Lake Monte Alegre, predation rates are not so high (ca. 14-fold lower), but the other two characteristics were observed. Therefore, they may potentially represent one of the main factors in controlling zooplankton prey populations in Lake Monte Alegre.

Density fluctuations of the mite Krendowskia sp. and of prey in the lake, in 1998/1999, showed that the highest peaks of Chaoborus sp. and Daphnia gessneri coincided with low predator densities (Fig. 2). As the cladoceran is also preyed on by Chaoborus, its highest peaks occurred when both predator densities were low. Correlation between mite and prey densities resulted in negative but not statistical significant values. In the lake, other factors besides predation are influencing prey populations, what might explain the lack of significant correlations.

Acknowledgments - We thank Dr. Beatriz E. Rosso, from Universidad Nacional de Cordoba, in Argentina, for the water mite identification and FAPESP (São Paulo State Foundation for Research Support) for grants to C. R. C. (n. 99/100529) and M. S. M. C. N. (n. 99/01251-8). We also thank Cláudia Fileto for providing field data, as well helping in the laboratory, and Luiz Fernando Netto for helping in direct observations. Thanks are due to an anonymous referee for valuable suggestions on an earlier version of the manuscript.

\section{REFERENCES}

ARCIFA, M. S., 2000, Feeding habits of Chaoboridae larvae in a tropical Brazilian reservoir. Rev. Brasil. Biol., 60: 591-597.

ARCIFA, M. S., MESCHIATTI, A. J. \& GOMES, E. A. T., 1990, Thermal regime and stability of a tropical shallow reservoir: Lake Monte Alegre, Brazil. Rev. Hydrobiol. trop., 23: 271-281.

ARCIFA, M. S., GOMES, E. A. T. \& MESCHIATTI, A. J., 1992, Composition and fluctuations of the zooplankton of a tropical Brazilian reservoir. Arch. Hydrobiol., 123: 479-497.

ARCIFA, M. S. \& MESCHIATTI, A. J., 1993, Distribution and feeding ecology of fishes in a Brazilian reservoir: Lake Monte Alegre. Interciencia, 18: 302-313.

BALSEIRO, E. G., 1992, The role of pelagic water mites in the control of clodoceran populations in a temperate lake of Southern Andes. J. Plankton. Res., 14: 1267-1277.

BUTLER, M. I. \& BURNS, C. W., 1991, Prey selectivity of Piona exigua, a planktonic water mite. Oecologia, 86: 210-222.

BUTLER, M. I. \& BURNS, C. W., 1993, Water mite predation on planktonic Cladocera: parallel curve analysis of functional responses. Oikos, 66: 5-16.

DAVIDS, C., BEINTEMA, E. F., MULDER, R. \& WEEKENSTROO, J. E., 1981, Feeding rate and egg production in water mites in relationship with temperature. Verh. Int. Ver. Limnol., 21: 1603-1606.

ERIKSSON, M. O. G., HENRIKSON, L. \& OSCARSON, H. G., 1980, Predator-prey relationships among water-mites (Hydracarina) and other freshwater organisms. Arch. Hydrobiol., 88: 146-154.

FILETO, C., 2001, O zooplâncton do Lago Monte Alegre: variação temporal e a influência das frações do fitoplâncton sobre o crescimento e reprodução de cladóceros. Dissertação de Mestrado, Faculdade de Filosofia, Ciências e Letras de Ribeirão Preto, USP, 100p.

GLIWICZ, Z. M. \& BIESIADKA, E., 1975, Pelagic mites (Hydracarina) and their effect on the plankton community in a neo-tropical man-made lake. Arch. Hydrobiol., 76: 65-88.

KERFOOT, W. C., KELlOGG Jr., D. L. \& STRICKLER, J. R., 1980, Visual observations of live zooplankters: evasion, escape, and chemical defenses, pp. 10-27. In: W. C. Kerfoot (ed.), Evolution and ecology of zooplankton communities. The University Press of New England, Hanover, 793p.

MATVEEV, V. T. \& MARTINEZ, C. C., 1990, Can water mites control populations of planktonic Cladocera? Hydrobiologia, 198: 227-231.

MATVEEV, V. T., MARTINEZ, C. C. \& FRUTOS, S. M., 1989, Predatory-prey relationships in subtropical zooplankton: water mite against cladocerans in an Argentine lake. Oecologia, 79: 489-495. 
MESCHIATTI, A. J. \& ARCIFA, M. S., 2002, Early life stages of fish and the relationship with zooplankton in a tropical Brazilian reservoir: Lake Monte Alegre. Braz. J. Biol., 62: 1-8.

PERTICARRARI, A., 2000, Migração vertical de microcrustáceos, Chaoboridae e Hydracarina no Lago Monte Alegre. Dissertação de Mestrado, Faculdade de Filosofia, Ciências e Letras de Ribeirão Preto, USP, 94p.

PROCTOR, H. C. \& PRITCHARD, G., 1990, Prey detection by water mite Unionicola crassipes (Acari, Unionicolidae). Freshwat. Biol., 23: 271-279.

RIESSEN, H. P., 1980, Diel vertical migration of pelagic water mites, pp. 129-137. In: W. C. Kerfoot (ed.), Evolution and ecology of zooplankton communities. The University Press of New England, Hanover, 793p.

RIESSEN, H. P., 1982a, Pelagic water mites: their life history and seasonal distribution in the zooplankton community of a Canadian lake. Arch. Hydrobiol. Supp., 62: 410-439.
RIESSEN, H. P., 1982b, Predatory behavior and prey selectivity of the pelagic water mite Piona constricta. Can. J. Fish. Aquat. Sci., 39: 1569-1579.

RIESSEN, H. P., 1985, Exploitation of prey seasonality by a planktonic predator. Can. J. Zool., 63: 1729-1732.

THRELKELD, S. T., RYBOCK, J. T., MORGAN, M. D., FOLT, C. L. \& GOLDMAN, C. R., 1980, The effects of an introduced predator and food resource variation on zooplankton dynamics in an ultraoligotrophic lake, pp. 555-568. In: W. C. Kerfoot (ed.), Evolution and ecology of zooplankton communities. The University Press of New England, Hanover, 793p.

ZARET, T., 1980, Predation and freshwater communities. Edwards Brother Inc., Ann Arbor, Mich., 187p. 